\title{
PENGARUH PERBEDAAN LAMA WAKTU KEJUTAN PANAS TERHADAP DAYA TETAS (Hatching Rate) PADA METODE GYNOGENESIS MEIOSIS IKAN MAS (Cyprinus carpio)
}

\author{
Achmad Sudianto \\ Staf Pengajar Program Ilmu Perikanan dan Kelautan \\ Universitas PGRI Ronggolawe Tuban
}

\begin{abstract}
ABSTRAK
Untuk meningkatkan kualitas induk, indukan ikan mas (Cyprinus carpio) perlu dimurnikan sehingga menghasilkan galur murni. Keberhasilan pembenihan ikan mas, khususnya di fase pembesaran ditentukan oleh kualitas benih. Program pemijahan dan pembenihan yang dikembangkan saat ini melalui Gynogenesis. Gynogenesis adalah proses pembenihan menggunakan gamet betina tanpa campur tangan dari gen gamet jantan. Penelitian ini menggunakan design/metode penelitian menggunakan rancangan acak lengkap (completely randomized design/CRD) dengan 3 perlakuan dengan 3 ulangan. Analisa menggunakan analisa varian, dengan memperhatikan distribusi tabel $\mathrm{F}$ atau Ftest yang dibandingkan dengan nilai $\mathrm{F}_{\text {hitung }}$ pada $\mathrm{F}_{\text {tabel }}$. berdasarkan analisa hasil penelitian terdapat pengaruh lama waktu kejutan panas terhadap daya tetas telur ikan mas (Cyprinus carpio) dengan metode Gynogenesis. Hasil penelitian menunjukkan perlakuan A menunjukkan hasil optimal dengan rata-rata 17,33, perlakuan B 12,33 dan perlakuan C sebesar 7 . Berdasarkan perhitungan Anova $\mathrm{F}_{\text {value }}(47,29)>\mathrm{F}_{1 \%}(18,00)$ tapi lebih besar $\mathrm{F}_{5 \%}(6,49)$ dengan ini $\mathrm{H}_{1}$ ditolak dan $\mathrm{H}_{0}$ diterima dengan hasil sangat nyata.
\end{abstract}

Kata kunci : Kejutan panas, Meiosis Gynogenesis, Tingkat penetasan.

\begin{abstract}
To improve the quality of the parent, the parent needs to be purified race carp (Cyprinus carpio) that exist so that the resulting pure strain. The success of seed carp, especially at this stage of the enlargement is determined by the quality of the seed. Breeding programs developed at this time is the method gynogenesis. Ginogenesis method is the process of female gamete without interference from male gamete gene. The experimental design used in this study is completely randomized design (CRD) is equipped with 3 treatments and 3 replications. Analysis using analysis of variance, with the distribution tabel $\mathrm{F}$ or $\mathrm{F}$ test that compares the value of $\mathrm{F}$ arithmetic with $\mathrm{F}$ tabel.Based on the analysis of research data on the influence of the length of time a different heat shock against the hatchability of eggs carp (Cyprinus carpio) method gynogenesis meiosis, based on the results of research, treatment A showed optimal results with an average 17.33, treatment B showed 12. 33 and $\mathrm{C}$ treatment showed 7.00. Based on calculations obtained ANOVA calculated $\mathrm{F}$ value (47.29)> F 1\% (18.00) but larger than F 5\% (6.49) then $\mathrm{H} 1$ is rejected at the level of $\mathrm{a}=1 \%$ and $\mathrm{H} 0$ highly significant conclusions (hight significant).
\end{abstract}

Key words : Heat Shock, Gynogenesis Meiosis, Hatching rate. 


\section{PENDAHULUAN}

Ikan mas adalah salah satu jenis ikan air tawar, bentuk tubuhnya panjang dan agak bulat dengan kepala kecil, punggung tinggi dan seluruh badannya bersisik besar (Murtidjo, 2001).

Perkembangan budidaya ikan mas (Cyprinus carpio) di Indonesia mengalami kemajuan pesat dengan sistem pembudidayaan yang bermacam-macam. Namun, intensifnya teknologi pemeliharaan ikan tidak akan membentuk benih unggul tanpa diikuti dengan usaha perbaikan genetik (Mair, 2003).

Untuk memperbaiki kualitas induk, perlu dilakukan pemurnian ras induk ikan mas (Cyprinus carpio) yang ada sehingga dihasilkan galur murni. Salah satu usaha memacu produksi adalah dengan meningkatkan kualitas benih dengan cara program pemuliaan yang tepat (Rustidja, 2002).

\section{Program pemuliaan yang berkembang saat ini adalah metode gynogenesis. Metode gynogenesis ini merupakan suatu proses dari gamet betina tanpa campur tangan dari gen gamet jantan} (Purdom, 2003).

Proses pemurnian dengan cara mengambil genetik murni yang berasal dari induk ikan betina dengan cara merangsang untuk terjadinya proses pembuahan tanpa adanya sumbangan atau campur tangan dari genetik induk ikan jantan (sperma yang telah dinonaktifkan dan digunakan hanya untuk memacu terjadinya perkembangan sel telur menjadi larva). Proses yang telah dilakukan ini adalah dengan cara metode gynogenesis meiosis (Stevanus, 2011).

Terdapat beberapa proses yang dilakukan dalam metode gynogenesis yaitu: pemberian penyinaran sperma dengan menggunakan kotak UV untuk menonaktifkan sperma, pemberian kejutan panas untuk menahan loncatan polar body II dan pemberian suhu dingin (Bambang, 2001).

$$
\text { Menurut Minjoyo (2003), }
$$
perhitungan telur dilakukan setelah telur menetas secara sempurna.

Menurut Zairin (2002), untuk mencari daya tetas telur (Hatching rate) dengan menggunakan rumus sebagi berikut:

$$
\begin{aligned}
& \text { HR }=\frac{\sum \text { telur yang menetas }}{\Sigma \text { telur yang ditetaskan }} \times 100 \% \\
& \text { Faktor-faktor yang mempengaruhi } \\
& \text { terhadap kelangsungan daya tetas } \\
& \text { (Hatching rate) adalah: suhu, oksigen } \\
& \text { terlarut (DO), derajat keasaman (pH), } \\
& \text { salinitas dan intensitas cahaya (Said, } \\
& \text { 2008). }
\end{aligned}
$$




\section{METODE PENELITIAN}

\section{Tempat dan Waktu Penelitian}

Penelitian ini dilakukan di Instalasi Pengelola Budidaya Air Tawar (IPBAT) Punten Kecamatan Batu, Kota Batu, Provinsi Jawa Timur, pada tanggal $20 \mathrm{Mei}$ -10 juni 2015.

Materi penelitian ini adalah Perbedaan Lama Waktu Kejutan Panas Terhadap Daya Tetas (Hatching rate) Pada Metode Gynogenesis Meiosis Ikan Mas (Cyprinus carpio).

\section{Alat dan Bahan}

1. Alat

Peralatan yang digunakan dalam penelitian ini adalah : Aerator, Stopwatch, Heater, Kotak UV 15 W, Mangkuk, Cawan Petri, Selang, Spluit, Bulu Ayam, Tabung Reaksi, Saringan penetasan, Thermometer, Kamera, Alattulis, Bak fiber, $\mathrm{pH}$ Pen, Waterbath.

\section{Bahan}

Bahan yang digunakan dalam penelitian ini adalah : Induk ikan mas jantan dan betina, Telur ikan dan Sperma, Pakan Ikan, $\mathrm{NaCl}$ Fisiologis 0,9\%, Larutan laktat ringer's, Tisu, Telur ayam.

\section{Analisa Data}

Penelitian ini menggunakan 3 perlakuan dan 3 kali ulangan, maka akan terdapat 9 unit percobaan. Dengan menggunakan analisis of varian dengan tabel distribusi $F$ atau uji $F$ yaitu membandingkan nilai $\mathrm{F}_{\text {hitung }}$ dan $\mathrm{F}_{\text {tabel. }}$.

Perlakuan terdiri dari 3 taraf perlakuan kejutan panas.

Perlakuan A : 0,5 menit dalam 100 butir pada suhu $40^{\circ} \mathrm{C}$ setelah fertilisasi.

Perlakuan B : 1,5 menit dalam 100 butir pada suhu $40^{\circ} \mathrm{C}$ setelah fertilisasi.

Perlakuan C : 2,5 menit dalam 100 butir pada suhu $40^{\circ} \mathrm{C}$ setelah fertilisasi.

\section{HASIL DAN PEMBAHASAN}

\section{Hasil Perhitungan daya tetas}

Perhitungan daya tetas digunakan untuk menentukan optimalisasi lama waktu yang berbeda pada kejutan panas terhadap daya tetas.

Setelah telur menetas selama 3-4 hari maka dilakukan perhitungan telur, berdasarkan hasil data perhitungan akhir penelitian, kemudian dimasukan dalam tabel percobaan. 
Tabel 1. Data Hasil Pengamatan Perbedaan Lama Waktu Kejutan Panas Metode Gynogenesis Meiosis.

\begin{tabular}{cccc}
\hline \multirow{2}{*}{ Ulangan } & \multicolumn{3}{c}{ Perlakuan } \\
\cline { 2 - 4 } & 0,5 menit & 1,5 menit & 2,5 menit \\
\hline 1 & 20 & 12 & 7 \\
\hline 2 & 18 & 15 & 9 \\
\hline 3 & 14 & 10 & 5 \\
\hline Total & $\mathbf{5 2}$ & $\mathbf{3 7}$ & $\mathbf{2 1}$ \\
\hline Rata-rata & $\mathbf{1 7 . 3 3}$ & $\mathbf{1 2 . 3 3}$ & $\mathbf{7 . 0 0}$ \\
\hline
\end{tabular}

Sumber : Hasil Penelitian, 2015)

Keterangan :

$$
\text { 1,2,3 : ulangan }
$$

Perlakuan A : 0,5 menit, nilai rata-rata 17.33

Perlakuan $\mathrm{B}$ : 1,5 menit, nilai rata-rata 12.33

Perlakuan $\mathrm{C}: 2,5$ menit, nilai rata-rata 7.00

Dari hasil perhitungan pada tabel diatas diperoleh perlakuan $\mathrm{A}=0,5$ menit terjadi tingkat penetasan telur sangat besar dibandingkan dengan perlakuan $\mathrm{B}=1,5$ menit dan perlakuan $\mathrm{C}=2,5$ menit terjadi penurunan tingkat penetasan pada telur. Hal ini dikarenakan terjadinya loncatan polar body II pada perlakuan A : 0,5 menit, sedangkan pada perlakuan B : 1,5 menit dan perlakuan $\mathrm{C}: 2,5$ menit telah terja dipeloncatan polar body II. Selain itu semakin lama waktu pemberian kejutan panas yang diberikan maka akan semakin sedikit telur yang menetas dan telur mengalami kerusakan sehingga telur gagal menetas.
Data hasil pengamatan nilai rata-rata dapat dilihat di bawah ini :

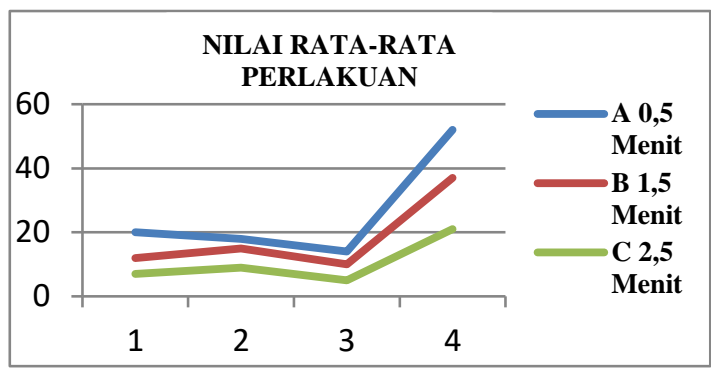

Grafik 3. Rata-rata Perlakuan daya tetas

*Sumber : Data Penelitian 2015

\section{Analisa Data}

Dilakukan uji statistik yaitu dengan menggunakan Anova hasil dapat dilihat dari tabel di bawah ini :

Tabel 2. Hasil Analisis Sidik Ragam

\begin{tabular}{|c|c|c|c|c|c|c|}
\hline & & & & $\mathrm{F}$ & & $\mathrm{F}$ \\
\hline & D & & & hitun & $\mathrm{F}$ & 1 \\
\hline SK & b & JK & KT & $\mathrm{g}$ & $5 \%$ & $\%$ \\
\hline Perlakua & & 199.5 & 99.7 & & 6.9 & \\
\hline $\mathrm{n}$ & 2 & 6 & 8 & 47.29 & 4 & 18 \\
\hline & & 160.2 & 80.1 & & & \\
\hline Ulangan & 2 & 2 & 1 & 37.97 & & \\
\hline Sisa & 4 & 8.44 & 2.11 & & & \\
\hline & & 368.2 & & & & \\
\hline Total & 8 & 2 & & & & \\
\hline
\end{tabular}

Hasil dari analisis sidik ragam menunjukkan perbedaan yang sangat nyata $\operatorname{dimana} F_{\text {hitung }}>F_{\text {tabel }(0,05)}=47.29>6.94$ dengan demikian terdapat perbedaan lama waktu kejutan panas dengan daya tetas telur ikan mas (Cyprinus carpio). 
Tabel 3. Hasil Uji BNT $5 \%$

\begin{tabular}{|c|c|c|c|}
\hline Perlakuan & Rata-rata & BNT 0.05 & BNT 0.01 \\
\hline C & 7 & a & a \\
\hline B & 12.33 & bc & a \\
\hline A & 17.33 & d & c \\
\hline
\end{tabular}

Sumber : Data Penelitian 2015

Uji BNT di atas menunjukan hasil penetasan yang optimal terdapat pada perbedaan lama waktu kejutan panas 0,5 menit dengan nilai rata-rata 17.33, kemudian diikuti dengan perbedaan lama waktu kejutan panas 1,5 menit dengan nilai rata-rata 12.33 dan pada perbedaan lama waktu kejutan panas 2,5 menit menunjukan hasil penetasan paling rendah dengan nilai rata-rata 7.

\section{Kualitas Air Pada Bak Penetasan}

Pengukuran kualitas air pada bak penetasan meliputi suhu, oksigen terlarut (DO) dan derajat keasaman $(\mathrm{pH})$ dapat dilihat pada tabel dibawah ini :

Tabel 4. Hasil Pengukuran Kualitas Air

\begin{tabular}{ccc}
\hline No. & Parameter & Kadar \\
\hline 1. & Suhu & $29-30^{\circ} \mathrm{C}$ \\
\hline 2. & Derajat Keasaman $(\mathrm{pH})$ & 7 \\
\hline 3. & Oksigen Terlarut $(\mathrm{DO})$ & $7,2 \mathrm{mg} / \mathrm{l}$ \\
\hline
\end{tabular}

\section{Pembahasan}

Pada perlakuan perbedaan lama waktu kejutan panas 0,5 menit, 1,5 menit, dan 2,5 menit dengan padat tebar 100 butir telur pada suhu $40^{\circ} \mathrm{C}$ dalam saringan, dengan demikian pada perlakuan A dengan lama waktu perendaman 0,5 menit menunjukan hasil penetasan yang terbaik dengan rata-rata 17.33 butir dibandingkan dengan perlakuan $\mathrm{B}=12.33$ butir dan $\mathrm{C}$ dengan nilai rata-rata 7 butir, maka dengan demikian dijelaskan pada perbedaan lama waktu kejutan panas pada perlakuan $\mathrm{A}=$ 0,5 disebabkan karena terjadinya peloncatan pada polar body II , sedangkan perbedaan lama waktu kejutan panas pada perlakuan $\mathrm{B}=1,5$ dan perbedaan lama waktu kejutan panas pada perlakuan $\mathrm{C}=$ 2,5 telah terjadi peloncatan polar body II dan semakin lama kejutan panas yang diberikan maka semakin sedikit telur yang menetas, dikarenakan telur yang rusak dan menghasilkan larva haploid (1N) yang gagal berkembang dan mati setelah beberapa hari.

Berdasarkan hasil penjelasan di atas Perlakuan A, B, dan $\mathrm{C}$, hasil dari perlakuan A menunjukan waktu yang optimal dan tingkat penetasan yang tinggi.

\section{KESIMPULAN}

Gynogenesis merupakan teknik rekayasa genetika untuk menghasilkan keturunan yang kita inginkan. Berdasarkan hasil penelitian mengenai pengaruh perbedaan lama waktu kejutan panas yang berbeda terhadap daya tetas telur ikan mas (Cyprinus carpio) dengan metode 
Gynogenesis meiosis, dapat diambil kesimpulan sebagai berikut :

1. Terdapat perbedaan yang sangat nyata (hight significant) pada pengaruh lama waktu kejutan panas yang berbeda terhadap daya tetas telur ikan mas (Cyprinus carpio) menunjukkan bahwa nilai $\mathrm{F}_{\text {hitung }}=47.29>\mathrm{F}_{5 \%}(6,94)$.

2. Berdasarkan pengukuran parameter kualitas air dalam bak fiber tidak mengalami perbedaan yang signifikan sehingga proses penetasan tidak terganggu.

\section{DAFTAR PUSTAKA}

Bambang, A.M. 2001 Beberapa Metode Pembenihan Ikan Mas Air Tawar. Kanisius. Yogyakarta.

Mair G. C., 2003. Cromosoe-Set Manipulation in TilapiaTecniques, Problem and Prospect. Aquaculture. 111: 227- 244 hal,

Murtidjo, A, B, 2001. Beberapa Metode Pembenihan ikan Air Tawar. Jl. Cempaka 9, Hal 67, Yogyakarta.

Minjoyo, H. 2003. Teknik Pembenihan Ikan Air Tawar. Penebar Swadaya, Jakarta.

Purdom. E. C. 2003. Genetika and fish breeding. Chapman and Hall. Fish and fisheries series, 277

Rustidja, 2002. Aplikasi Manipulasi Kromosom pada Program
Pembenihan Ikan. Makalah pada Kongres Ilmu Pengetahuan Nasional V di Jakarta 3-7 September. 18 hal.

Said, D. S. 2008. Viabilitas reproduksi dan pertumbuhan ikan melanotaenia praecox pada habitat terkontrol. Bogor.

Stevanus. 2011. Stevanusjendelausaha.blogspot.com/2011/ 04/gynogenesis.html. Diakses dari internet pada kamis, 2 februari 2012.

Zairin, M. 2002. Sex Reversal Memproduksi Benih Ikan Jantan atau Betina. Penebar Swadaya. Jakarta. 